\title{
Trans-Siberian Permian rivers: A key to understanding Arctic sedimentary provenance
}

\author{
Victoria B. Ershova a,*, Andrey K. Khudoley a , Andrei V. Prokopiev ${ }^{\text {b }}$, Marianna I. Tuchkova ${ }^{\text {c }}$, Petr V. Fedorov ${ }^{\text {a }}$, \\ Galina G. Kazakova ${ }^{\mathrm{a}, 1}$, Sergey B. Shishlov ${ }^{\text {a }}$, Paul O'Sullivan ${ }^{\mathrm{d}}$
}

a Institute of Earth Sciences, St. Petersburg State University, Universitetskaya nab. 7/9, St. Petersburg 199034, Russia

b Diamond and Precious Metal Geology Institute, Siberian Branch, Russian Academy of Sciences, Lenin Pr. 39, Yakutsk 677980, Russia

c Geological Institute, Russian Academy of Science, Pyzhevsky Per. 7, Moscow 119017, Russia

d GeoSep Services, 1521 Pine Cone Road, Moscow, ID 83843, USA

\section{A R T I C L E I N F O}

\section{Article history:}

Received 6 July 2015

Received in revised form 9 March 2016

Accepted 20 March 2016

Available online 23 March 2016

\section{Keywords:}

Siberia

Arctic

Permian

Detrital zircon

Paleogeography

Provenance

\begin{abstract}
A B S T R A C T
Permian strata of northern Siberia contain a rich record of the late Paleozoic history of Siberia and surrounding fold and thrust belts (FTB). More than 850 uranium-lead (U-Pb) detrital zircon ages collected from the Permian strata provide vital information about sediment source areas and history of the sedimentary basins. The detrital zircon populations obtained from the Permian clastics of northern Siberia are characterized by large percentages of late Paleozoic and early Paleozoic zircons, whose ages can be correlated with magmatic events known from the Ural-Mongolian Orogen. Our data suggest that Permian clastics of northern Siberia were mainly sourced from orogens developed along the western and southwestern margins of the Siberian Craton (in present-day coordinates), with an additional sediment contribution from the reworked sedimentary cover and basement of Siberia. The contribution from Siberian sources is distinguished in the Precambrian part of the detrital zircon populations by wide distribution of ca. 1700-2000 Ma and 2500-2750 Ma zircons with an almost total lack of zircons ranging in age from 800 to $1700 \mathrm{Ma}$. We propose that a major fluvial system, which we here term the "Paleo-Khatanga", was the main sediment transport pathway along the western and northern margins of Siberia during the Permian. From a regional overview of detrital zircon populations in Permian deposits across the Arctic realm, we propose that the New Siberian Islands, Alexander and Farewell terranes were sourced from the western framework of the Ural-Mongolian Orogen and were located along the northern margin of Baltica during the late Paleozoic. The Arctic-Alaska-Chukotka Terrane on the other hand does not have Uralian signatures in the detrital zircon populations of the Permian sediments, and can be reconstructed adjacent to the northern margin of Laurentia. Our new data presented here help to better define the enigma of Arctic paleogeography during the Paleozoic.
\end{abstract}

(c) 2016 Elsevier B.V. All rights reserved.

\section{Introduction}

The number of detrital zircon U-Pb studies in the Arctic has substantially increased in recent years, providing new constraints on the paleogeographic and tectonic evolution of this complex region. However, only a handful of $\mathrm{U}-\mathrm{Pb}$ detrital zircon studies have been conducted on the Paleozoic successions of Siberia and its margins (Prokopiev et al. 2008; Miller et al. 2013; Ershova et al. 2013, 2015d; Prokopiev et al. 2013, Zhang et al. 2013; Glorie et al. 2014; Khudoley et al. 2015). Here we provide an overview of the stratigraphy and depositional environments of Permian deposits across northern and central Siberia, along with a provenance study based on $\mathrm{U}-\mathrm{Pb}$ dating of detrital zircons from 9 samples collected from the Permian strata in northern Siberia.

\footnotetext{
* Corresponding author.

E-mail address: v.ershova@spbu.ru (V.B. Ershova).

1 Currently at All Russia Geological Research Institute (VSEGEI), Sredny Pr. 74, St. Petersburg, 199,106, Russia.
}

The Permian deposits of northern Siberia are represented by a thick succession of clastic rocks deposited in various continental, brackish and marine paleoenvironmental settings. These strata provide a record of the Permian tectonic history along the northern margin (present-day coordinates) of Siberia and surrounding fold and thrust belts (FTB). Consequently, they form an important basis for the reconstruction of fluvial pathways across Siberia in late Paleozoic. Our detrital zircon data obtained from the Permian strata of northern Siberia provide a unique signature which can be used to locate and identify other terranes of Siberian affinity, which are now scattered across the Arctic and Cordilleran realm following opening of the Mesozoic-Cenozoic sedimentary basins.

\section{Geological background}

The study area is located along the northern margin of the Siberian Craton and surrounding FTB (Figs. 1 and 2). The Siberian Craton represents the northeastern part of the Eurasian Plate and is bound on all 


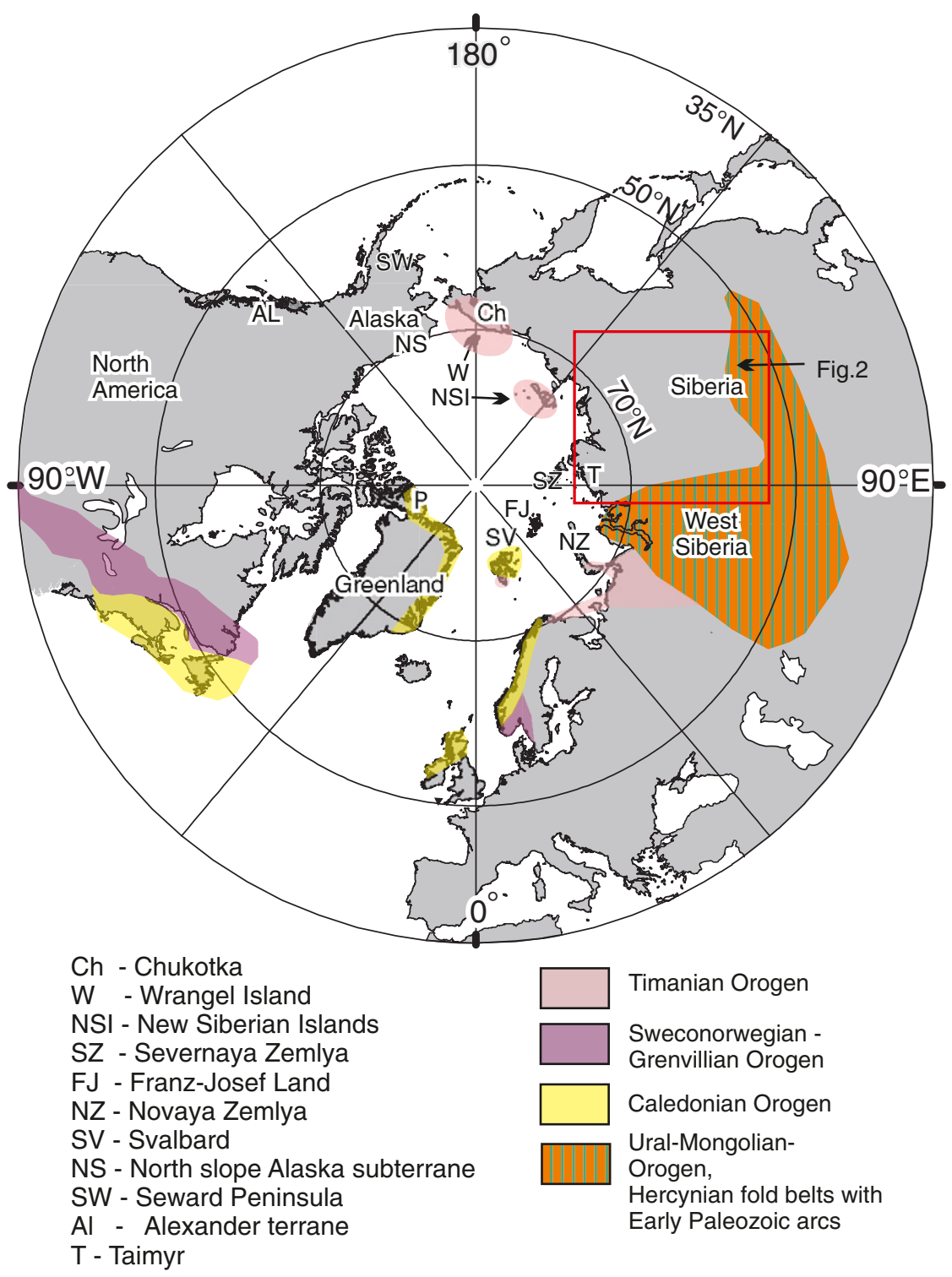

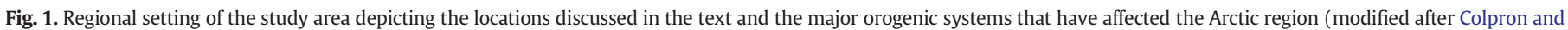
Nelson, 2011).

sides by FTB of Precambrian-Mesozoic age, mainly the result of terrane accretion onto the margins of Siberia during the late Precambrian - Jurassic. The Siberian Craton is an ancient Precambrian complex of Archean and Paleoproterozoic terranes, which were amalgamated at 2.01.85 Ga (Rozen, 2003; Smelov and Timofeev, 2007). Precambrian basement outcrops in the Anabar Shield and Olenek Uplift in the north of the craton, and in the Aldan Shield in the south (Fig 2). Neoproterozoic magmatic rocks have not been described from the basement of Siberia, but have been described from the Yenisey Ridge along the southwestern margin (Vernikovsky et al., 2004; Vernikovskaya et al., 2006; Nozhkin et al., 2008, 2013), and from the Taimyr Peninsula along the northern margin (Fig.2) (Vernikovsky, 1996; Vernikovsky et al., 2004; 2011; Zakharov et al., 1993; Pease and Vernikovsky, 1998; Pease et al., 2001; Proskurnin et al., 2014). The Siberian basement is overlain by a Proterozoic to Mesozoic sedimentary cover of varying thickness and composition, including the Permian stratigraphy described below.

\section{Overview of stratigraphy}

In the present-day structural framework, Permian deposits are widely distributed along the northern, eastern and western margins of
Siberia, including the surrounding South Taimyr and Verkhoyansk FTB which represent deformed Paleozoic-Mesozoic passive margins of Siberia (Figs. 2 and 3). Within the Siberian Craton and in the Yenisey-Khatanga and Lena-Anabar depressions information on the Permian rock unit composition and thickness is based mainly on the well and seismic studies. The thickness and facies of Permian deposits vary significantly across Siberia. Brief descriptions are provided below.

\subsection{Tunguska area}

The Lower Permian deposits are mostly represented by alternating sandstones, siltstones and clays, mainly deposited in continental environments, with numerous relatively thick coal beds described through the succession (Fig. 4) (Budnikov, 1976). Shallow-marine to brackish water deposits have been reported from the northern part of the area, where the uppermost Lower Permian deposits comprise clayey limestone with numerous bivalves. The Middle-Upper Permian deposits are mainly sandstones with beds of clays and siltstones. Thick coal beds are reported from the upper part of the succession and conglomeratic layers occur 


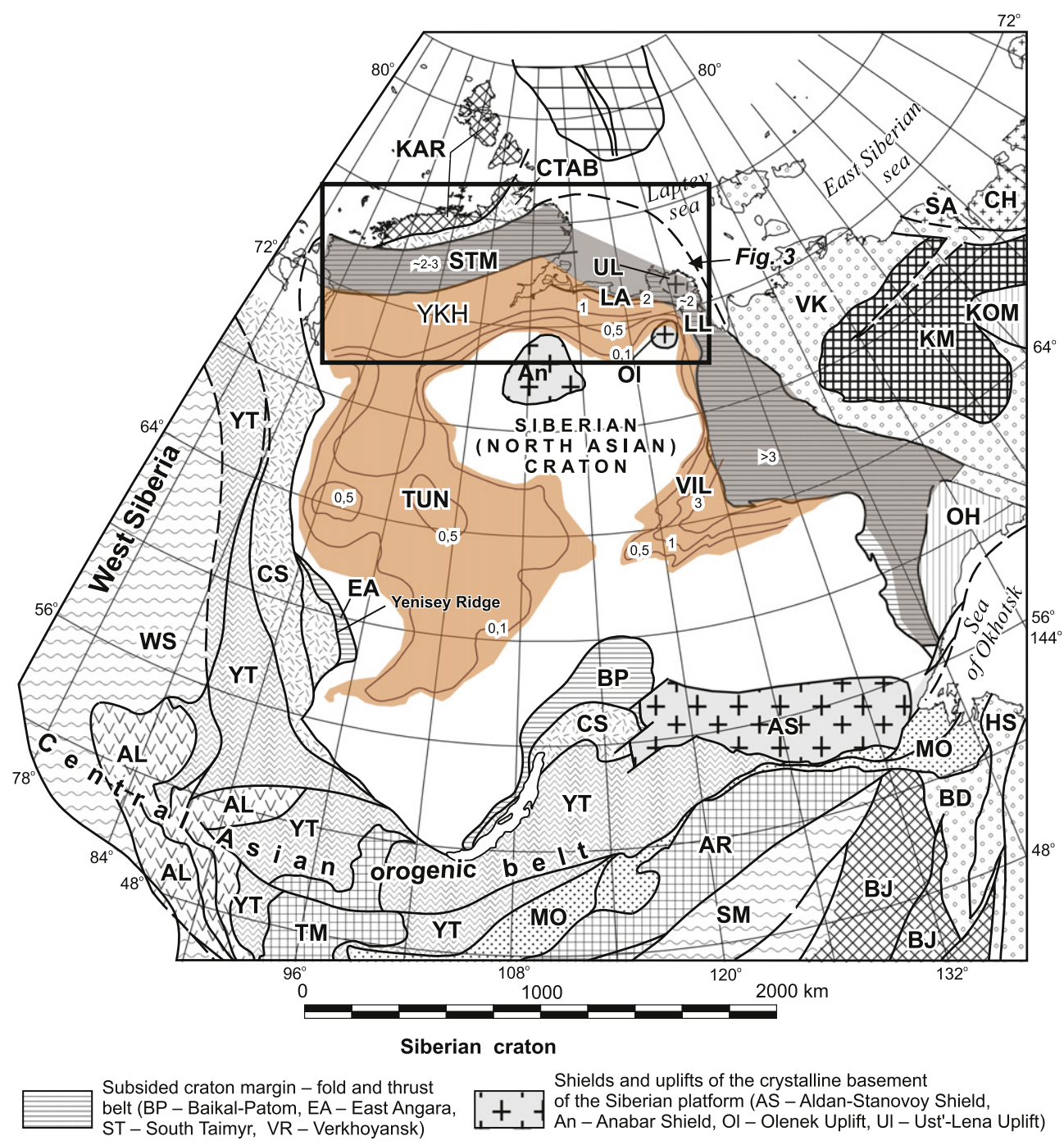

Orogenic belts and their fragments

Circum-Siberia (CS), Central Taimyr
accretionary belt (CTAB), Neoproterozoic
Yenisey-Transbaikal (Late Cambrian
to Early Ordovician)

Fig. 2. Map of cratons and orogenic belts of Northeast Asia with present-day distribution of Permian strata and accompanying thickness (after Parfenov et al., 2003, 2009, modified).

sporadically throughout the succession (Budnikov, 1976). The thickness of Permian deposits varies significantly across the area, from $100 \mathrm{~m}$ to approximately $1000 \mathrm{~m}$, increasing from the south to the north and from the margins to the central part of the basin (Fig. 2).

\subsection{South Taimyr FTB}

The Permian deposits here have been intensely deformed during Mesozoic compression, complicating correlation and thickness estimation across the region (e.g. Shishlov, 2003). Permian strata are widely 

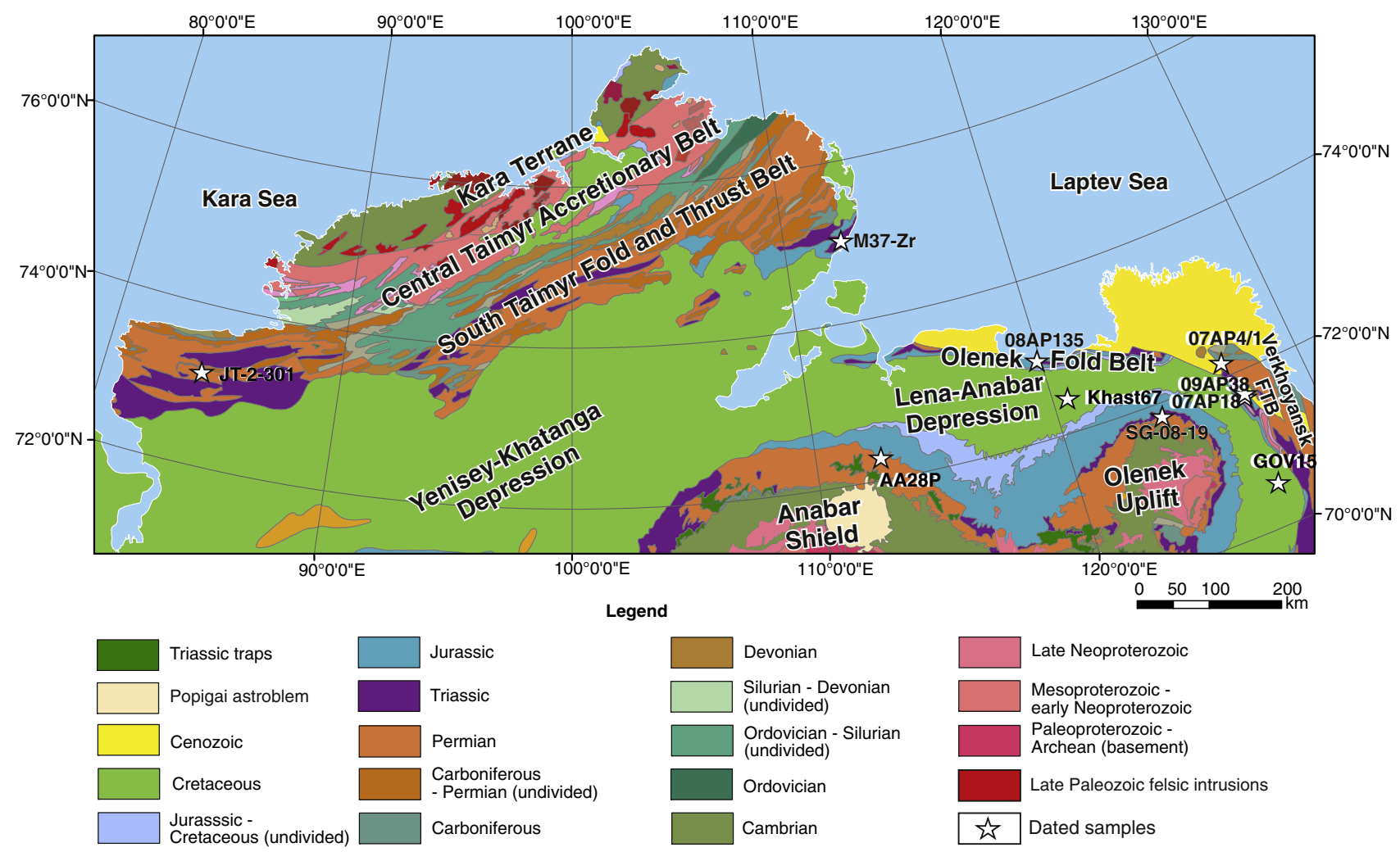

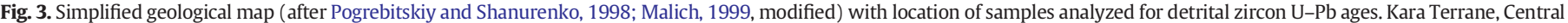
Taimyr Accretionary Belt and South Taimyr FTB comprise the Taimyr-Severnaya Zemlya Orogenic Belt.

distributed in the South Taimyr FTB (Figs. 2 and 3). The Lower Permian deposits are represented by alternating marine clays, siltstones and limestones in the northwest, and intercalated clays, siltstones and sandstones with beds of coal in the southwest and east (Pogrebitskiy and Shanurenko, 1998; Pogrebitskiy and Lopatin, 1999) (Fig.4). Uppermost Lower Permian deposits are represented by continental sandstones with lenses and beds of conglomerates in the northwest of Taimyr, and shallow marine to lagoonal sandstones in the east. The uppermost Lower-Middle Permian deposits consist of interbedded siltstones, sandstones and clays across the region, with marine fossils reported from the eastern part of Taimyr (Pogrebitskiy and Shanurenko, 1998). The uppermost Middle-Upper Permian deposits are mainly continental sandstones, siltstones and clays with numerous coal beds. Rare bivalves from the uppermost Middle-Upper Permian deposits present evidence of a temporary brackish water environment (Pogrebitskiy and Shanurenko, 1998; Pogrebitskiy and Lopatin, 1999). The thickness of Permian deposits varies from 2 to $3 \mathrm{~km}$ across the South Taimyr region (Fig. 2).

\subsection{Lena-Anabar Depression}

The Permian deposits within the Lena-Anabar Depression are mostly covered by a thick Mesozoic succession (Fig. 3). They outcrop along the northern margins of the Anabar Shield and Olenek Uplift, and within the Olenek Fold Belt, while elsewhere they are penetrated by several wells. The whole Permian succession comprises interbedded sandstones, siltstones and clays, with numerous coal beds (Fig. 4). Permian strata in this area display a facies zonation from entirely continental deposits in the south, only a few tens of meters thick, to brackish and marine clastics up to $2400 \mathrm{~m}$ thick in the north (Fig. 2) (Kontorovich et al., 2013; Pogrebitskiy and Shanurenko, 1998).

\subsection{Lower Lena area}

Permian strata across much of the lower Lena area are covered by a thick Mesozoic succession, and only outcrop along the eastern margin of the Olenek uplift and in the Kharaulakh Mountains (northern part of the Verkhoyansk FTB) (Fig. 3), and are found in a few wells. Permian sediments display a facies transition from entirely continental deposits in the west to deltaic-submarine fan deposits in the east, with an increase in thickness from a few hundred meters to a few kilometers in the same direction (Fig. 2). The continental sediments in the west comprise sandy deposits with layers of conglomerates, fining eastwards to interbedded siltstones, clays and sandstones (Mezhvilk and Markov, 1983; Solomina, 1997).

\subsection{Vilyui area}

The Permian strata in the Vilyui area outcrop along the northwest margin of the Vilyui basin and are penetrated within the basin by deep wells. They are mainly represented by continental to shallow marine clastics and contain numerous coal beds, overlying Upper Cambrian-Carboniferous ${ }^{2}$ deposits along the margins. The thickness of Permian deposits varies from a few tens of meters along the periphery of the basin to $3200 \mathrm{~m}$ in the central part (Fig. 2) (Prokopiev et al., 2001). The Permian deposits of the adjacent Verkhoyansk FTB are intensively deformed and represented by alternating clays, siltstones and sandstones deposited in deltaic-submarine fan environments, attaining a thickness of several kilometers (Prokopiev et al., 2001; Khudoley and Prokopiev, 2007).

\footnotetext{
${ }^{2}$ We follow the subdivision of Carboniferous on 2 parts: Early Carboniferous $=$ Mississippian, Late Carboniferous $=$ Pennsylvanian .
} 


\section{Chronostratigraphic chart}

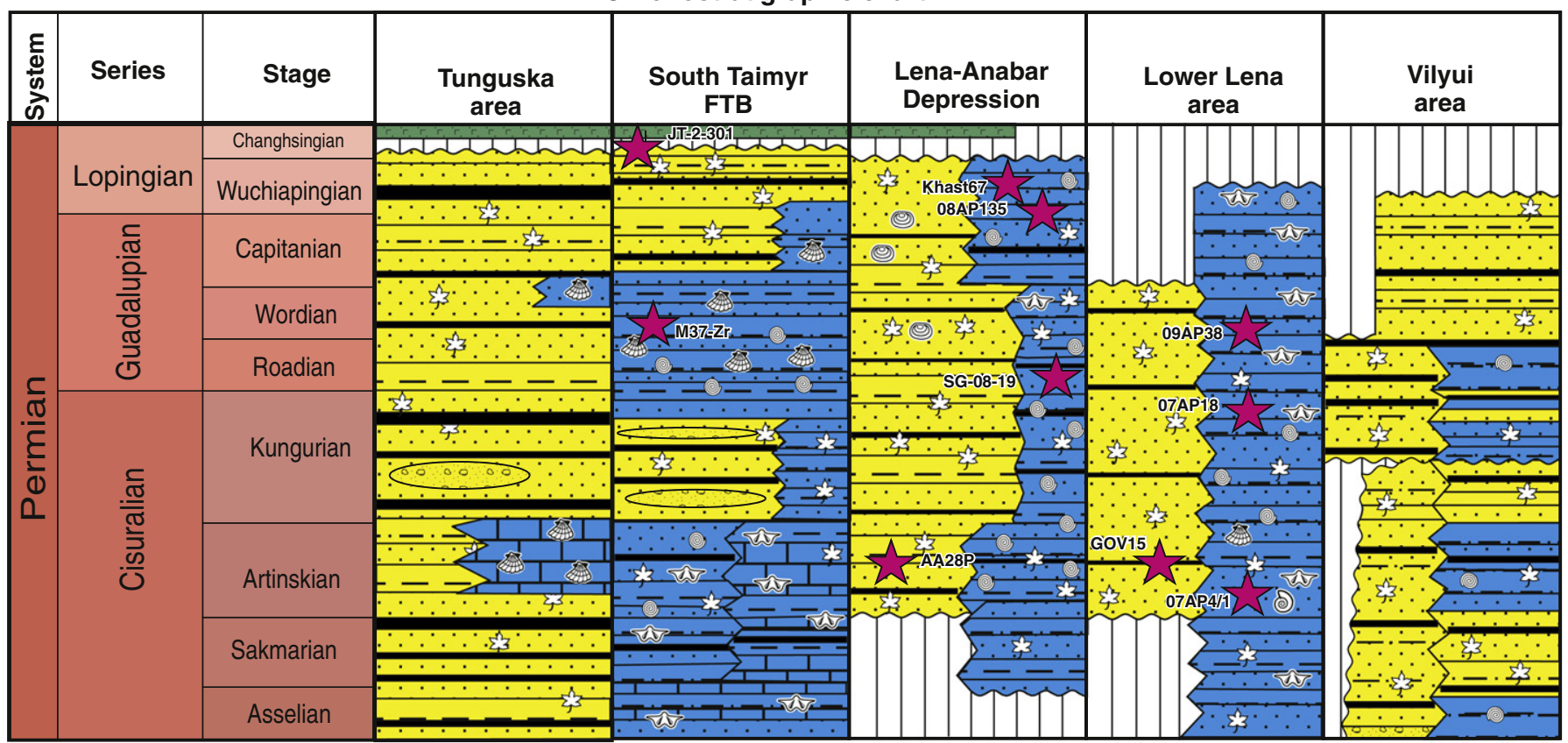

Sketch map showing distribution of

Legend:

\begin{tabular}{|c|c|c|c|}
\hline 1 & Limestone & & Coal \\
\hline & Clay & $\infty$ & Brachiopods \\
\hline & Siltstone & () & Foraminiferas \\
\hline & Sandstone & (a) & Fresh water bivalves \\
\hline & Conglomerates & 姆 & Marine bivalves \\
\hline & Tuffs & (2) & Ammonites \\
\hline & $\begin{array}{l}\text { Continental } \\
\text { environments }\end{array}$ & $\xi 3$ & Flora \\
\hline & $\begin{array}{l}\text { Marine } \\
\text { environments }\end{array}$ & 08AP135 & Dated sample \\
\hline
\end{tabular}
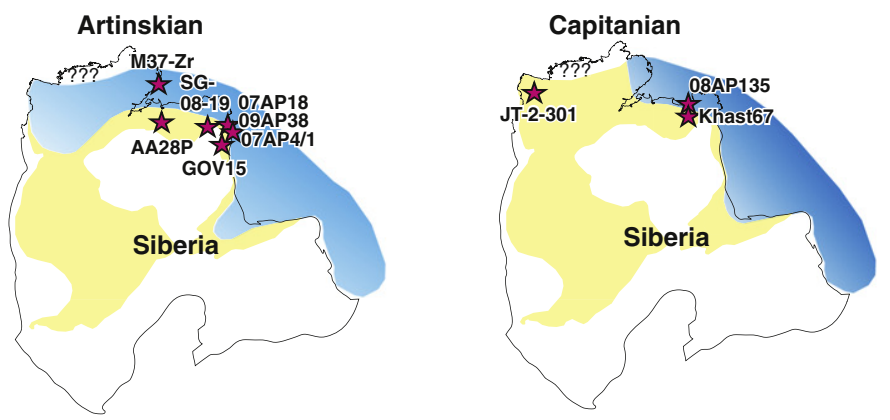

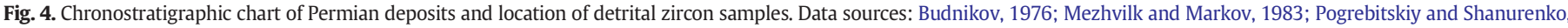

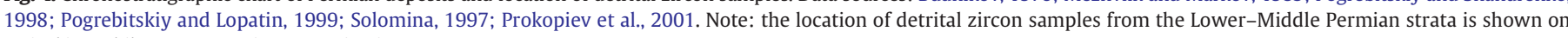
Artinskian while Upper Permian on Capitanian map.

\subsection{Yenisey-Khatanga Depression}

The Permian strata of the Yenisey-Khatanga Depression are covered by a thick Mesozoic succession and were not penetrated by any wells within the basin. Thus we can only predict the composition and thickness of Permian strata by making inferences from known outcrops in the Tunguska basin to the south, and across Taimyr to the north, and using seismic data in the Yenisey-Khatanga Depression (Kushnir, 2006). This leads us to also expect a complete Permian succession within the Yenisey-Khatanga basin. According to the seismic data, in the westernmost part of the Yenisey-Khatanga Depression the total thickness of undivided Carboniferous-Lower Triassic strata is estimated at approximately $10 \mathrm{~km}$, although up to $3 \mathrm{~km}$ may be Lower Triassic traps (Kushnir, 2006).

\subsection{West Siberian sedimentary basin}

Permian deposits are also covered by a thick Mesozoic succession in the West Siberian sedimentary basin and penetrated only in deep wells. Permian strata are mostly represented by continental deposits filling in local depressions and their distribution is limited across the West Siberian sedimentary basin (Yolkin et al., 2001).

\section{Detrital zircon $\mathrm{U}-\mathrm{Pb}$ analyses}

$\mathrm{U}-\mathrm{Pb}$ dating of detrital zircons was performed on 9 samples. Samples were crushed and the heavy minerals were concentrated using standard techniques at the Institute of Precambrian Geology and Geochronology, Russian Academy of Science, and Diamond and Precious Metal Geology Institute, Siberian Branch of Russian Academy of Sciences. The zircon grains were mounted in epoxy and polished. $\mathrm{U}-\mathrm{Pb}$ analyses were carried out by Apatite to Zircon, Inc. and at the LaserChron Center (University of Arizona), with ${ }^{207} \mathrm{~Pb} /{ }^{206} \mathrm{~Pb}$ ages reported for $>1.0 \mathrm{Ga}$ grains and ${ }^{206} \mathrm{~Pb} /{ }^{238} \mathrm{U}$ ages for $\leq 1.0 \mathrm{Ga}$ grains. Following Gehrels (2012), analyses with greater than 30\% discordance and $10 \%$ reverse discordance were excluded. Data tables with information on grains that fit discordance criteria and a detailed description of analytical procedures are provided in Attachment 1 and explanation text. The complete results of the $\mathrm{U}-\mathrm{Pb}$ study are illustrated in Figs 5-6. 

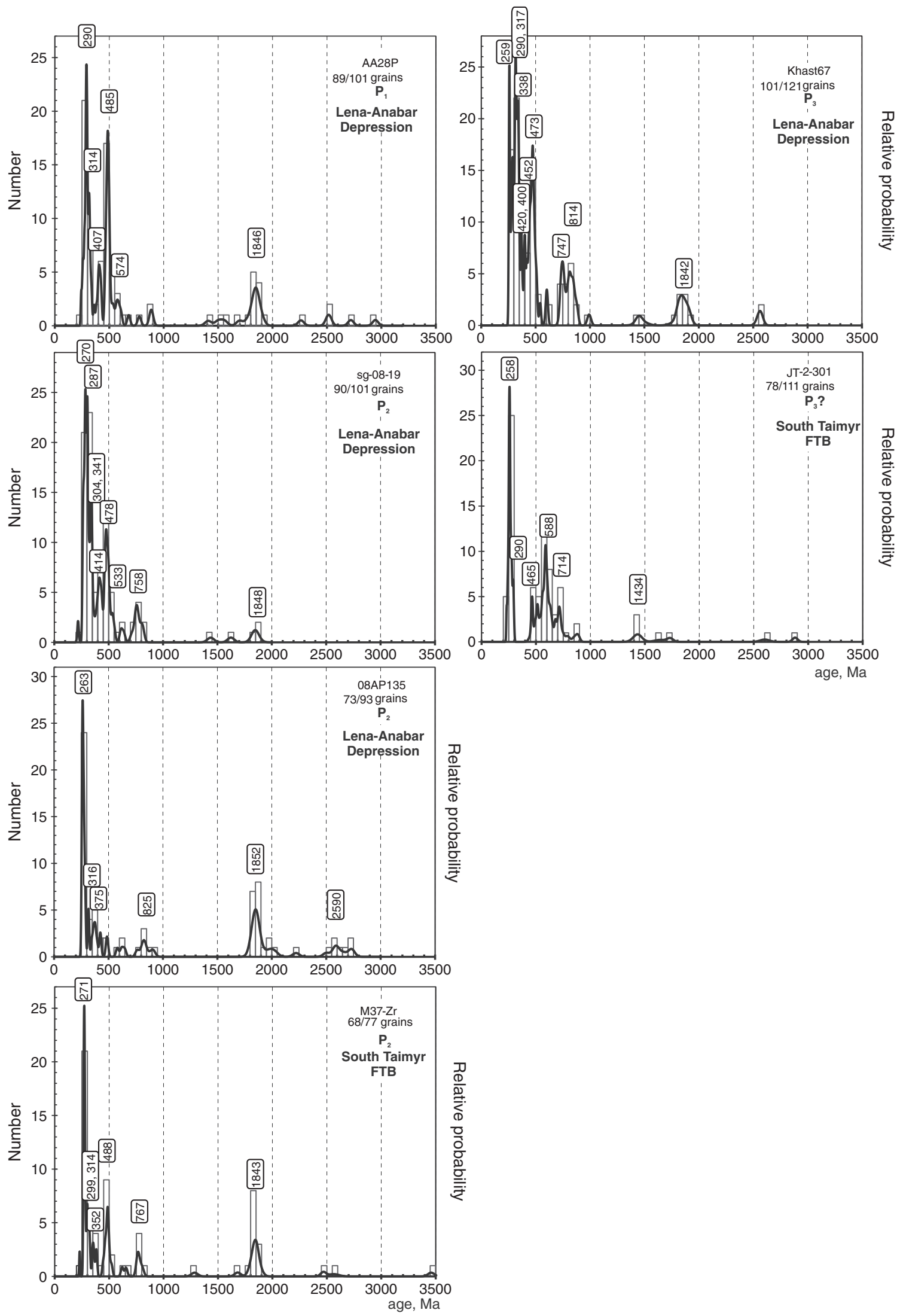

Fig. 5. Probability density diagram and superimposed histogram of U-Pb detrital zircon ages from Permian rocks of South Taimyr FTB and Lena-Anabar Depression. 

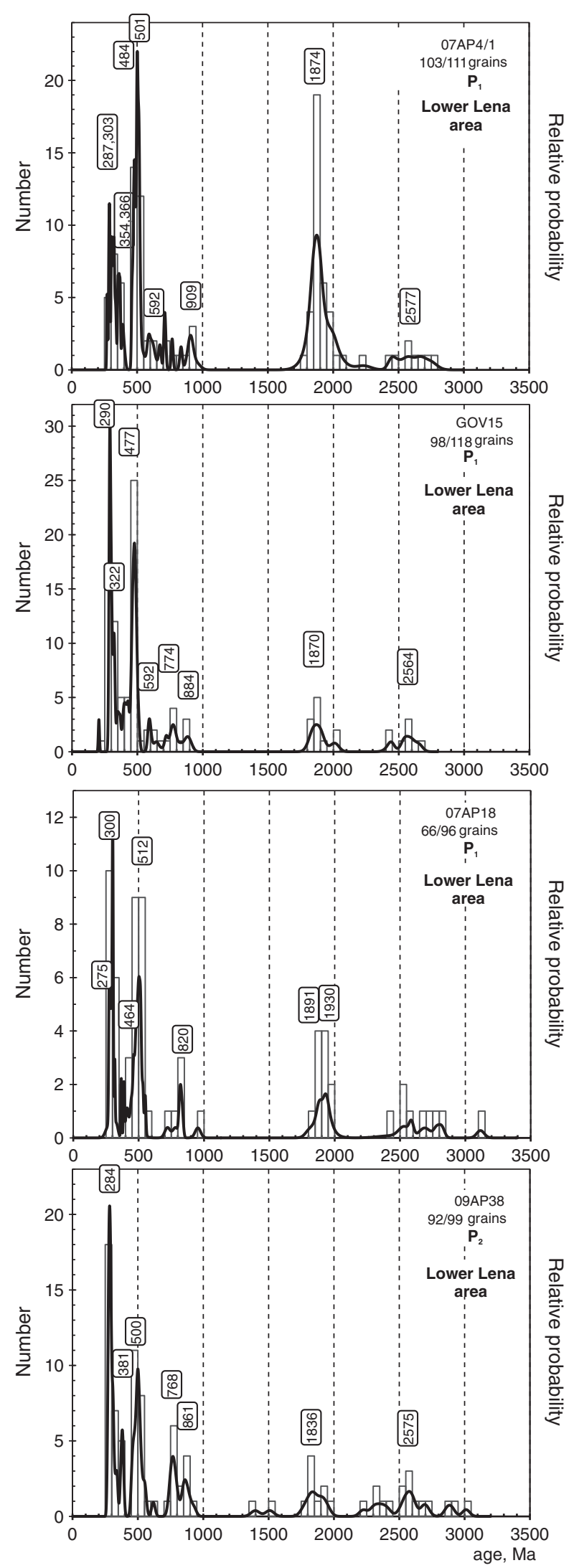

Fig. 6. Probability density diagram and superimposed histogram of U-Pb detrital zircon ages from Permian rocks of Lower Lena area.

\subsection{South Taimyr FTB}

Two samples (Jt-2-301 and M37-Zr) from Upper Permian deposits were analyzed. The Jt-2-301 sample was collected in western part of South Taimyr FTB (Figs. 3-5). It was located below Triassic basalts, in rock units correlated with uppermost Permian. The sample contains a few grains displaying Early Triassic ages, but they do not form a prominent peak and therefore were not used to constrain the depositional age of sedimentation. Fifty one percent of the dated grains are Precambrian in age. Neoproterozoic grains contribute $42 \%$ of the total population and form major peaks at 715 and $588 \mathrm{Ma}$. A few Archean, Paleoproterozoic and Mesoproterozoic grains recovered do not form prominent peaks. Early Paleozoic grains contribute $14 \%$ of the total population and form a peak at 465 Ma. Permian grains comprise $29 \%$ and form two peaks at 290 and $258 \mathrm{Ma}$. Devonian-Carboniferous zircon ages were absent within the dated grains.

The M37-Zr sample was collected in eastern part of South Taimyr FTB from Middle Permian deposits (Figs. 3-5). The three Archean grains do not form a prominent peak. Paleoproterozoic grains comprise $21 \%$ of the population and are grouped into a peak around $1845 \mathrm{Ma}$. A single Mesoproterozoic grain yielded an age of $1261 \pm 50$ Ma. Neoproterozoic grains comprise $10 \%$ of the population and form an age group around 767 Ma. The early to middle Paleozoic grains comprise $22 \%$ of the population and form a distinct peak at $488 \mathrm{Ma}$, and Carboniferous-Permian grains (41\%) form peaks at ca. 352, 314, 299 but most cluster around $271 \mathrm{Ma}$.

\subsection{Lena-Anabar area}

The four samples (AA28P, SG0819, 08AP135, Khast67) dated in this region have a similar detrital zircon age distribution (Figs. 3-5). The Precambrian grains comprise 18 to $49 \%$ of the total population, with $\mathrm{Ar}$ chean grains ranging between 2500 and $2950 \mathrm{Ma}$, and a few Mesoproterozoic grains with ages clustering around 1500-1600 Ma. Neoproterozoic and Paleoproterozoic grains were the most abundant among the Precambrian zircons with peaks around 1845, 820 and $750 \mathrm{Ma}$. Also found were early to middle Paleozoic zircons with prominent peaks at ca. 480, 415 and $400 \mathrm{Ma}$. Carboniferous and Permian ages comprise from 34 to $51 \%$ of the dated grains and group around 340,315 , 290 and $270 \mathrm{Ma}$.

\subsection{Lower Lena area}

The detrital zircon signatures of four dated samples (07AP4/1, GOV15, 07AP18, 09AP38) (Figs. 3, 4 and 6) from the Permian rocks are similar. Archean grains comprise from 6 to $12 \%$ and form a peak at ca. 2560-2580 Ma. Paleoproterozoic grains typically comprise $12-15 \%$ of the total population and are grouped into a peak varying in age from 1835 to $1930 \mathrm{Ma}$. The highest number of Paleoproterozoic grains was documented in the sample 07AP4/1 (38\% of the total population) with a peak at $1875 \mathrm{Ma}$. Only two Mesoproterozoic grains were found in a single sample (09AP38) with ages of $1387 \pm 32$ and $1508.7 \pm$ 32 Ma. Neoproterozoic grains comprise from $11 \%$ to $18 \%$ of the zircon population and their ages group at 880-900, 770-780 and $590 \mathrm{Ma}$. The Paleozoic grains comprise $44 \%$ to $65 \%$ of the grains and form numerous peaks. Early to middle Paleozoic grains form peaks at 500, 480, 465, 420 and $380 \mathrm{Ma}$, and Carboniferous-Permian grains grouped at ca. 355, 300, 290 and 275 Ma.

\section{Provenance and paleogeographic interpretation}

There is a striking similarity in the age distribution of detrital zircons from Permian strata across the study region (Fig. 7) pointing to the same provenance area for dated samples. The Archean grains mainly vary in age from 2500 to 2750 Ma but do not form significant peaks. Rocks of this age are known from the oldest terranes constituting the 


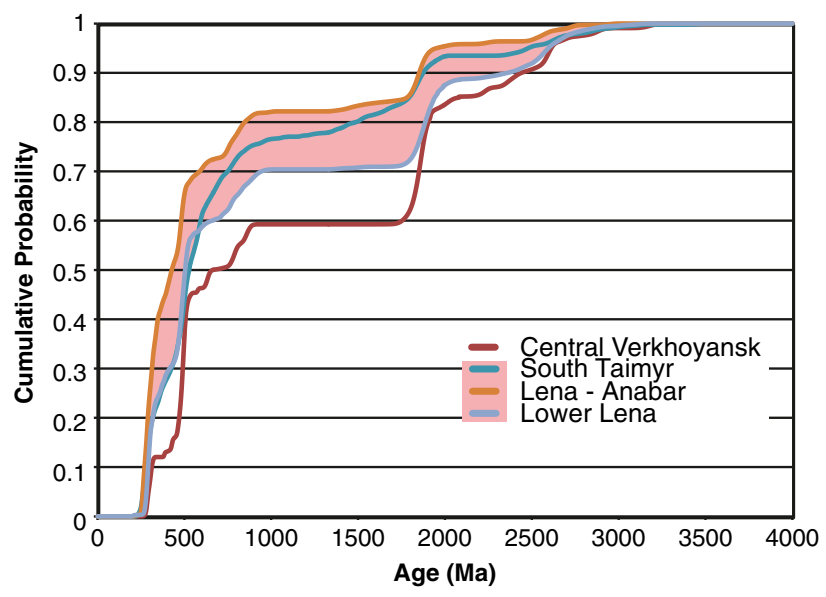

Fig. 7. Cumulative probability density plot of $U-P b$ ages for Permian strata of South Taimyr FTB, Lena-Anabar Depression and Lower Lena area (this study) and Central Verkhoyansk (Prokopiev et al., 2008). Rose color highlights similarity in distribution of DZ within studied areas.

basement of the Siberian Craton (Rozen, 2003; Smelov and Timofeev, 2007).The Paleoproterozoic grains form a distinctive peak in all dated samples and are grouped mainly around 1830-1880 Ma. Rocks of this age are reported within the basement of the Anabar Shield (Gusev et al., 2013), but they are significantly more widespread across the southern and southwestern margins of Siberia (Smelov and Timofeev, 2007; Prokopiev et al., 2008). Following these samples there is a significant time gap among the detrital zircon ages. The next relatively weak peaks in the age probability occur in the Neoproterozoic at around 700$800 \mathrm{Ma}$, although some samples include older peaks ranging broadly between 800 and $900 \mathrm{Ma}$. Neoproterozoic igneous rock of similar age have been described from the Yenisey Ridge along the southwestern margin of Siberia (Vernikovskaya et al., 2006; Nozhkin et al., 2008; 2013) and the Taimyr Peninsula along the northern margin (Vernikovsky, 1996; Vernikovsky et al., 2004; 2011; Zakharov et al., 1993; Pease and Vernikovsky, 1998; Pease et al., 2001; Proskurnin et al., 2014). Paleozoic ages dominate and are mostly group into two major populations of Ordovician and Late Carboniferous-Permian age. All samples contain Permian age peaks consistent with their stratigraphic age, pointing to erosion of a contemporaneous orogen.

Detrital zircon ages among samples analyzed indicate that northern Siberian Permian clastic strata were derived from erosion of magmatic and/or metamorphic rocks related to several orogenic cycles. Likely sources are early Paleozoic magmatic and volcanic rocks that are described from: the Urals (Puchkov, 1997; 2009), Kazakhstan (Degtyarev, 2012 and references therein); southern Siberia (Turkina et al., 2007 and references therein); and Severnaya Zemlya (Lorenz et al., 2007). The dominance of Carboniferous-Permian zircon populations can be correlated to different magmatic episodes reported from the Ural-Mongolian Orogen. The collision during Uralian orogeny is characterized by magmatic activity varying from late Early Carboniferous-Late Permian younging northwards (from Kazakhstan and Southern Urals to the Polar Urals) (Puchkov, 1997; 2009, Brown et al., 2006). Late Carboniferous-Permian collision-related granites are also known from the basement of the West Siberian sedimentary basin (Ivanov et al., 2010: 2012; 2013; Votyakov et al., 2013). Thus, the source areas for Permian clastics sampled are likely located within broad UralMongolian Orogen with contribution from the basement of Siberia and/ or sedimentary succession primarily sourced from basement rocks.

The Taimyr-Severnaya Zemlya Orogenic Belt (Fig. 3) has been previously considered as a northern branch of the Urals due to occurrence of Late Permian igneous intrusions (Vernikovsky, 1996), and Taimyr Permian deposits are interpreted as the infill of a rapidly subsiding foreland basin located along the thrust front. However, more recent dating of the granites in northern Taimyr and Severnaya Zemlya gives Early-earliest Middle Carboniferous ages (Makariev, 2013). This indicates that a collision between the Kara Terrane (northern Taimyr and Severnaya Zemlya Archipelago) and Siberian Craton occurred earlier than previously assumed. The distribution of detrital zircons from Carboniferous clastics of northern Siberia also partly supports an Early Carboniferous collision event (Ershova et al., 2013: 2015d; Prokopiev et al., 2013). However, clastic sediment supply from the northern provenance (Kara Terrane) was significantly reduced by the end of Carboniferous. Most Permian granite intrusions dated in Taimyr Peninsula by $\mathrm{Rb}-\mathrm{Sr}$ isochron and $\mathrm{U}-\mathrm{Pb}$ zircon methods are Middle to Late Permian (Vernikovsky, 1996) whereas our samples contain numerous Early Permian detrital zircon grains which are unlikely to have been sourced from the Taimyr-Severnaya Zemlya Orogenic Belt.

Moreover, the Permian successions provide evidence for the existence of marine basins across the northern and eastern margins of Siberia during Early Permian, while continental (fluvial and lacustrine) sedimentation prevailed in the Tunguska basin (western margin of Siberia) and in the Vilyui Basin (Figs. 3 and 4). The Middle-Late Permian strata of northern Siberia are characterized by a transition to continental environment, in the westernmost part of Taimyr, with still shallow marine to deltaic sedimentation prevailing in the eastern Taimyr, and most part of Lena-Anabar and Lower Lena areas. Also there is an established facies transition from fluvial depositional environments, across the Tunguska area in the south, to marine environments in the north towards the Taimyr Peninsula and Lena-Anabar area. This suggests that the main provenance of clastic was located to the south and west of our study area.

A comparison of our Permian samples from northern part of Siberia with Permian samples dated previously by Prokopiev et al. (2008) from Central Verkhoyansk region shows a slight difference in the detrital zircon age distribution (Fig. 7). Also there is an increasing amount of Precambrian grains within Central Verkhoyansk succession indicating a more significant contribution from the Siberian basement. Prokopiev et al. (2008), based on data from the Central Verkhoyansk region, proposed a major fluvial system located in the central part of Siberia and named it the "Paleo-Lena River". This river flowed along the axis of the Vilyui Depression and transported clastics from southwestern Siberia to the Verkhoyansk passive margin across the Siberian Craton. Using the results of our detrital zircon study, along with evidence of the Permian succession facies transition, we propose that a major fluvial system, similar to that proposed for Carboniferous time, and termed the "PaleoKhatanga” (Ershova et al., 2013; 2015d; Prokopiev et al., 2013) would be the main sediment transport pathway along the western and northern margins of Siberia (Fig. 8). With this transport system the main source of clastic material would be in the eastern and southeastern part of Ural-Mongolian Orogen. Thus, the Permian paleogeography of Siberian continent was controlled by several major long-lived fluvial systems, with Paleo-Khatanga River in the north and Paleo-Lena River in the central part of it.

\section{Implications for the Arctic realm}

A number of recent late Paleozoic Arctic geodynamic reconstructions are based on detrital zircon data (Embry, 1998; Ershova et al., 2015a, b; Miller et al., 2006; 2010; 2013; Beranek et al., 2012; 2013; Tochilin et al., 2014; Gottlieb et al., 2014; Colpron and Nelson, 2011, and many others). The principal objective was to reconstruct the late Paleozoic positions of terranes which are now scattered across the Arctic and North American Cordillera before the opening of a number of Mesozoic-Cenozoic oceanic basins. We consider here only those terranes which have available detrital zircon data from Permian sediments. These include the Farewell Terrane, Alexander Terrane, Arctic Alaska-Chukotka Terrane, New Siberian Islands, Sverdrup basin (Arctic Canada) and Kara Terrane (Severnaya Zemlya Archipelago and Northern Taimyr). 


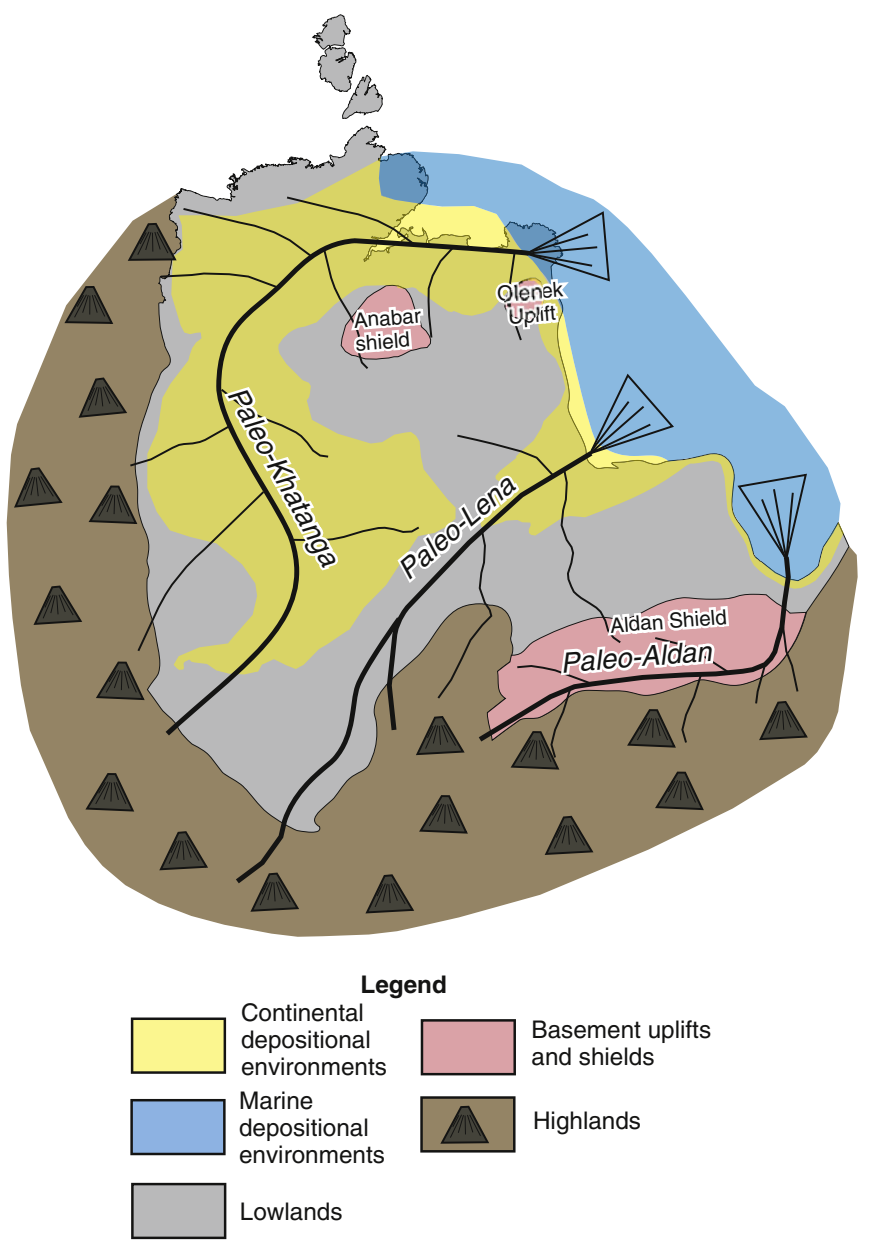

Fig. 8. Proposed Permian Paleo-Lena and Paleo-Khatanga river systems across Siberia (after Prokopiev et al., 2008; Ershova et al., 2015d, modified). Sedimentological data from Southern Verkhoyansk indicate that a separate drainage system fed that part of basin from south (Khudoley and Guriev, 1994).

\subsection{Existing models}

\subsubsection{Farewell Terrane}

There are a number of models regarding the late Paleozoic affinity of the Farewell Terrane. Dumoulin et al. (2002) considered the Farewell Terrane as a microcontinent within an ocean between the Siberian and Laurentian cratons, while Bradley et al. (2003) suggested that the terrane formed part of a plate convergence zone stretching from the Urals to the North America Cordillera. More recently, Colpron and Nelson (2011) considered the Farewell Terrane to represent a part of the Siberian Platform until at least Early Permian time. The most recent model by Malkowski and Hampton (2014) places the Farewell Terrane in the Panthalassic Ocean and proximal to peri-Laurentian terranes along the western margin of the Slide Mountain Ocean during the Pennsylvanian-Early Permian (Fig.9).

\subsubsection{Alexander Terrane}

There are also a number of different models for the location and movement of the Alexander Terrane during the late Paleozoic (Fig.9). There is reasonable consensus on a peri-Baltican location of the terrane in the early-middle Paleozoic (Beranek et al., 2012; 2013; Tochilin et al., 2014), however there is more of a disparity between different researchers regarding its middle-late Paleozoic history. Colpron and Nelson (2011) proposed that the Alexander Terrane moved from the
paleo-Arctic into the paleo-Pacific realm during the Paleozoic and Tochilin et al. (2014) assumed migration of the terrane from the Arctic into the Cordilleran realm in the late Paleozoic. Beranek et al. (2014) considered the Alexander Terrane as part of an Alexander-WrangelliaPeninsular composite terrane, placing it between the Uralian orogenic system of Eurasia and Cordilleran arc system, alongside the western Pangea terrane, during Permian time.

\subsubsection{Arctic Alaska-Chukotka Terrane}

Northern Alaska, Chukotka, and the adjacent continental shelves are often considered as components of a composite Arctic Alaska-Chukotka Terrane (AACT). Recent studies suggest that the AACT is composed of at least two different blocks which became amalgamated in Devonian or Carboniferous time (Lane, 2007; Strauss et al., 2013). Pre-Devonian rocks in the northeast of the North American part (North Slope subterrane) of the AACT have affinities to Laurentia (Gottlieb et al., 2014; Strauss et al., 2013), while the northwestern part of the North American part and Russian part of the AACT (Chukotka and Wrangel Island) have Baltican affinities (Amato et al., 2009; Miller et al., 2006; Miller et al., 2010; Till et al., 2014) (Fig.9).

\subsubsection{Novaya Zemlya Archipelago}

Novaya Zemlya Archipelago forms the eastern framework of the Barents Sea. It comprises the Neoproterozoic-Paleozoic succession located in the northern margin of Baltica (present-day coordinates) that was folded and thrusted during Uralian Orogeny (Korago et al. 1992; Lorenz et al., 2013 and references therein) (Fig.9). The Permian deposits there represent the distal part of the Cis-Uralian foreland basin stretching along the eastern margin of Baltica, and they are sourced from the western side of the Ural-Mongolian Orogen (Lorenz et al., 2013 and references therein). Thus, detrital zircon data from the Permian deposits of Novaya Zemlya Archipelago could be used as a reference point for reconstruction of terranes located to the west from the UralMongolian Orogen.

\subsubsection{Kara Terrane}

Various models have been proposed for the Paleozoic history of the Kara Terrane, which encompasses the Severnaya Zemlya Archipelago, northern part of the Taimyr Peninsula and northern Kara Shelf. Zonenshain et al. (1990) suggested that the terrane was part of an ancient continent called “Arctida”, while Lorenz et al. (2008a, b) described it as a marginal part of Baltica and other researchers suggested it existed as a separate microcontinental terrane until the late Paleozoic (Bogdanov et al., 1998; Gramberg and Ushakov, 2000; Metelkin et al., 2000; 2005).

\subsubsection{New Siberian Islands}

Several differing models regarding the affinity of the New Siberian Islands have been published in recent years (Kuzmichev, 2009; Ershova et al., 2015a, b; Metelkin et al., 2014). Kuzmichev (2009) suggested the New Siberian Islands represented the distal passive margin of Siberia, while Zonenshain et al. (1990) considered the New Siberian Islands as part of an ancient continent called "Arctida". Based on paleomagnetic data, Metelkin et al. (2014) considered the New Siberian Islands as a small microcontinental terrane located along the eastern margin of Siberia (present-day coordinates), but separated from it during the Neoproterozoic and Paleozoic (Fig.9). The most recent studies suggest reconstructing the New Siberian Islands Terrane along the northern margin of Laurentia and/or Baltica using upper Paleozoic detrital zircon geochronology (Ershova et al., 2015a, b). However, Pease et al. (2015), based on change in provenance between Devonian and Permian time from Baltica to a mixed Baltica-Uralian source suggested that the Uralian foreland basin extended from Taimyr to the New Siberian Islands. 


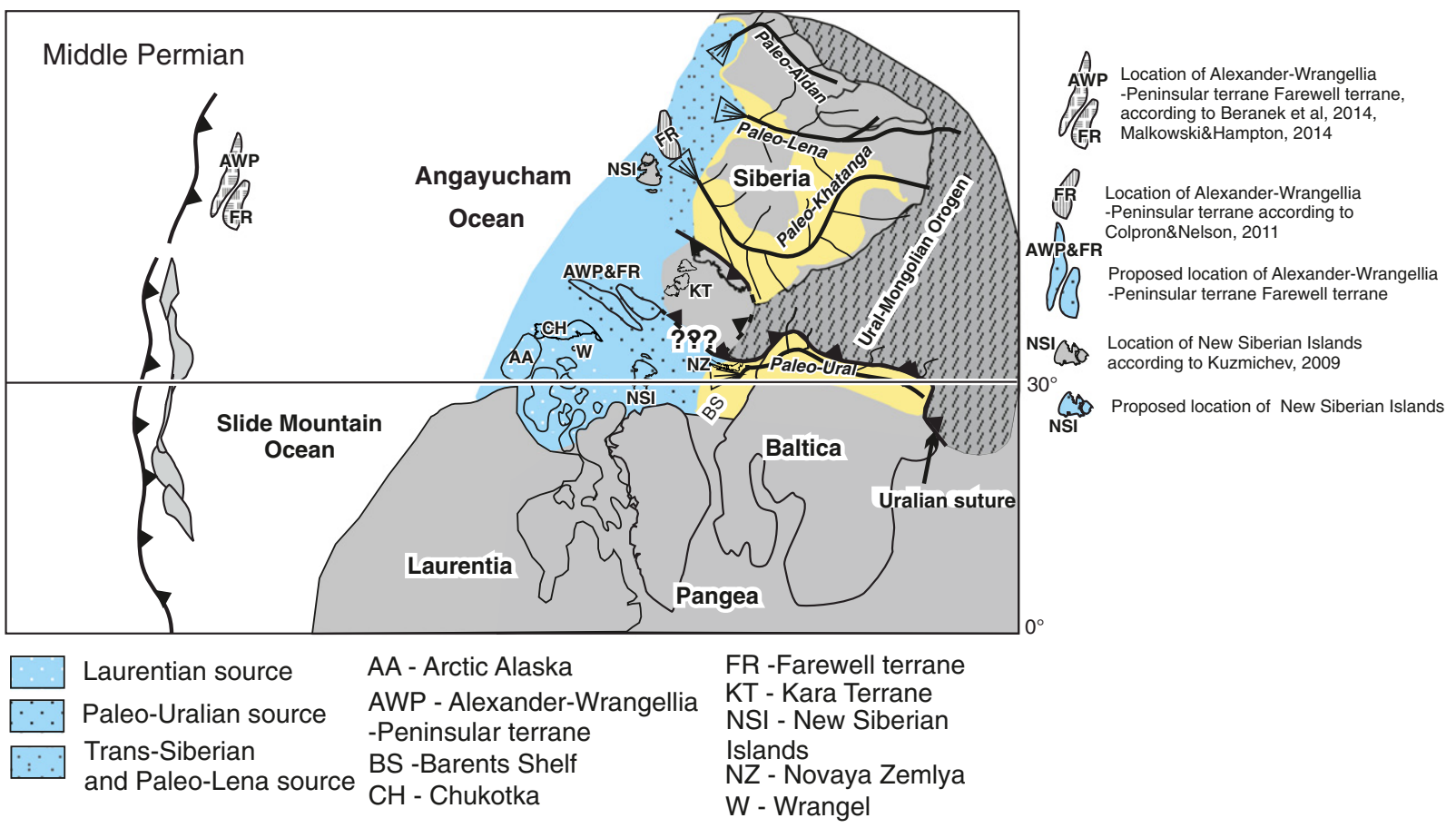

Fig. 9. The proposed Artic model for Middle Permian, modified after Lawver et al. (2002); Beranek et al. (2014).

6.2. Comparison of detrital zircon data from Permian strata across the Arctic realm

A review of available detrital zircon ages from Permian strata around the Arctic (Fig. 10) reveal two major groups. The first includes the Alexander and Farewell terranes, Novaya Zemlya and the New Siberian Islands, and Permian of Siberia (Lorenz et al., 2013; Tochilin et al., 2014; Malkowski and Hampton, 2014; Ershova et al., 2015a; 2015b; Pease et al., 2015) which show major zircon populations of Late Carboniferous-Permian age, that could be attributed to Uralian source. The second group comprises the AACT-Wrangel Island and north of Alaska, Severnaya Zemlya and the Sverdrup Basin (Lorenz et al., 2008b; Miller et al., 2010; Gottlieb et al., 2014; Ershova et al., 2015a, b, c, d; Anfinson et al., this issue) with no zircons close to the age of sedimentation.

The detrital zircon populations of the Alexander and Farewell terranes, Novaya Zemlya, and New Siberian Islands as well as in northern Siberia and Central Verkhoyansk are characterized by numerous Late Carboniferous-Permian and early Paleozoic grains, and Precambrian zircons are subordinate and are predominantly Paleoproterozoic and $\mathrm{Ar}$ chean in age (Fig. 10). In contrast, detrital zircon populations of the AACT, Wrangel Island, north of Alaska and the Sverdrup Basin contain numerous Mesoproterozoic grains with age peaks matching the ages of magmatic and metamorphic events within the GrenvillianSveconorwegian provenance (Bingen et al. 2008; Rivers 2008; McLelland et al. 2010) pointing to the Grenvillian-Sveconorwegian areas as the main source of clastic sediments.

The detrital zircon distribution from the Upper CarboniferousLower Permian sediments of the Severnaya Zemlya Archipelago does not show any similarities with other regions within the Arctic realm. Ershova et al. (2015c) explained this by predominance of the local erosion of Early Ordovician magmatic rocks across the archipelago.

Gottlieb et al. (2014) proposed that the source of Permian clastics of northern Alaska were locally reworked Devonian foreland clastic wedge as well as underlying Franklinian Basin strata (Anfinson et al., 2012a; 2012b). By contrast Miller et al. (2010) suggested that the Permian strata of Wrangel Island were derived from the marginal part of Baltica.
However striking similarities of distribution of detrital zircons from Permian strata of northern Alaska and Wrangel Island possibly point to the same source region for clastic detritus.

\subsection{Proposed model}

The late Paleozoic paleogeography of northern Eurasia is mainly controlled by accretionary and collision processes between Baltica, Kazakhstan and Siberia which led to formation a huge orogenic system (Ural-Mongolian Orogen) which occupies the modern Urals and extends further to the east under the sedimentary cover of West Siberia continuing south to frame the southern margin of Siberia (Puchkov, $1997 ; 2009)$. The eastern part of the Orogen provided clastics to Siberia where large river systems transferred clastic material to its northern and eastern margins (present-day coordinates), while the western part of the same orogen provided clastic material for deposits along eastern and northern margin of Baltica (present-day coordinates). The major question is whether it is possible to reposition present day Arctic and Cordilleran terranes to either Baltican or Siberian margins in late Paleozoic based on the provenance signature from terrigenous deposits, when the main source areas for these deposits were the eastern and western parts of the Ural-Mongolian Orogen.

At a regional scale, the detrital zircon age distributions from Permian strata around the Arctic (Fig. 10) reveal a similarity between detrital zircon ages from Permian deposits of Novaya Zemlya, New Siberian Islands, Alexander and Farewell terranes. Distribution of detrital zircon ages in Permian strata from these regions, with numerous Late Paleozoic grains, shows a fingerprint of Ural-Mongolian Orogen (Fig. 10). More detailed analyses of the Precambrian detrital zircon populations in these regions indicate contributions from Baltican rather than Siberian sources. That is there is no $800-1700$ Ma gap in detrital zircon populations as it has been found in Siberian sources. Furthermore, the Precambrian zircons show a close fit to Grenvillian-Sveconorwegian ages (Bingen et al., 2008; Rivers, 2008; McLelland et al., 2010) lacking in Siberia and its framework (e.g. Gladkochub et al., 2010; Khudoley et al., 2015). Based on the data presented here, we propose an alternative model that restores these terranes along the northern margin of Baltica 

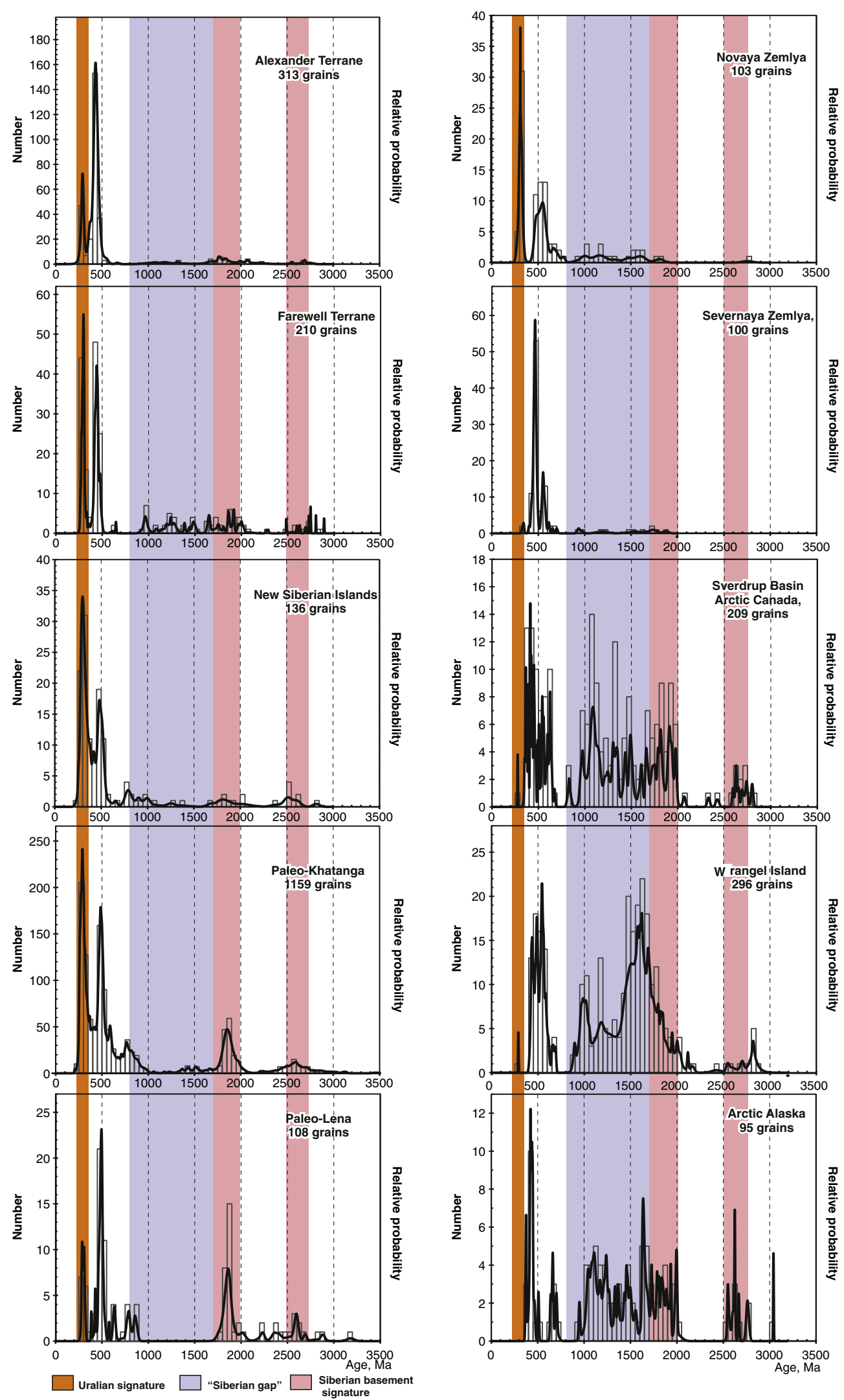

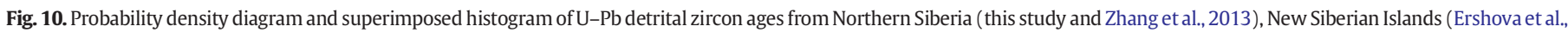

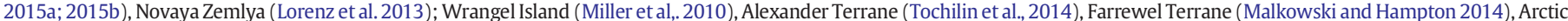

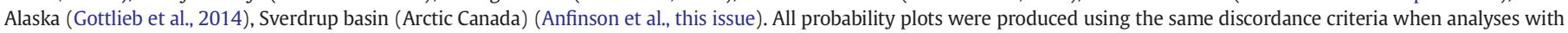
greater than $30 \%$ discordance and $10 \%$ reverse discordance were excluded. 
in late Palaeozoic (Fig. 9). This model supports reconstruction of earlymiddle Paleozoic location of New Siberian Islands and Alexander Terrane, as peri-Baltican terranes as suggested by Ershova et al. (in press) and Beranek et al. (2013). The detrital zircon age populations from the AACT, both from the Russian part (Wrangel Island) and North American part (North Slope subterrane), do not provide any evidence of a Uralian provenance, therefore we propose restoring this composite terrane to a position adjacent to the northern part of Laurentia during the late Paleozoic (Fig. 9).

\section{Conclusions}

The detrital zircon provenance analysis gives us a means of evaluating paleogeographic reconstructions for the late Paleozoic of northern Siberia. Our detrital zircon data suggest that Permian clastics of northern Siberia were mainly sourced from orogens framing the western and southwestern Siberia craton, with an additional sediment contribution from the reworked sedimentary cover, and basement, of Siberia. Our paleogeographic restoration necessitates the existence of major fluvial systems draining northward and eastward across Siberia during the Permian: the Paleo-Khatanga and the Paleo-Lena river systems.

The detrital zircon signatures of the Paleo-Khatanga and Paleo-Lena rivers are characterized by large percentages of Carboniferous-Permian and early Paleozoic zircons, which, along with reference to facies transitions of Permian rocks, can be tied to discrete magmatic events known from within the Ural-Mongolian Orogen rather than those of the north Taimyr and Severnaya Zemlya. The contribution from Precambrian Siberian sources is indicated by wide distribution of ca. 1700$2000 \mathrm{Ma}$ and 2500-2750 Ma zircons with a total lack of zircons within the 800-1700 Ma age range. This regional overview of detrital zircon age populations from Permian deposits across the broader Arctic realm helps to identify the pre-Mesozoic affinities of terranes which now lay many hundreds of kilometers apart. We propose that Permian clastics deposited on the New Siberian Islands, Alexander and Farewell terranes could be sourced from the western margins of the UralMongolian Orogen, and must therefore have been located along the northern margin of Baltica during the late Paleozoic. Meanwhile, Permian sediments on the AACT contain no evidence for Uralian signatures and could be restored adjacent to the northern margin of Laurentia. The new data presented in this paper help to redefine and place new constraints on late Paleozoic Arctic paleogeography prior to opening of the Mesozoic-Cenozoic oceanic basins.

\section{Acknowledgments}

Discussions with J. Barnet and M. Cecile and reviews by O. Anfinson, H. Lorenz and L. Lane greatly improved the initial manuscript. Fieldwork and significant part of the analytical study were supported by TGS. Analytical costs for 07AP18, 07AP4/1 samples were funded by the British Petroleum and by NSF-EAR 0948673 awarded to E.L. Miller. The research was also supported by RFBR grant 15-35-20591, research grant of Saint Petersburg State University 3.38.137.2014 and research program of DMPGI SB RAS VIII.66.1.4, Project 53 (RAS 44P). This paper is a contribution to IGCP \#592.

\section{Appendix A. Supplementary data}

Supplementary data to this article can be found online at http://dx. doi.org/10.1016/j.tecto.2016.03.028.

\section{References}

Amato, J.M., Toro, J., Miller, E.L., Gehrels, G.E., Farmer, G.L., Gottlieb, E.S., Till, A.B., 2009 Late Proterozoic-Paleozoic evolution of the Arctic Alaska-Chukotka terrane based on U-Pb igneous and detrital zircon ages: implications for Neoproterozoic paleogeographic reconstructions. Geol. Soc. Am. Bull. 121, 1219-1235.
Anfinson, O.A., Leier, A.L., Embry, A.F., Dewing, K. 2012a, Detrital zircon geochronology and provenance of the Neoproterozoic to Late Devonian Franklinian Basin, Canadian Arctic Islands: Geological Society of America Bulletin, v. 124(3-4), p. 415-430.

Anfinson, O.A., Leier, A.L., Gaschnig, R., Embry, A.F., Dewing., K., 2012b, U-Pb and Hf isotopic data from Franklinian Basin strata: insights into the nature of Crockerland and the timing of accretion, Canadian Arctic Islands: Can. J. Earth Sci., v. 49(11), p.1316-1328.

Anfinson, O.A., Embry, A.F., Stockli, D.F., 2016. Geochronologic Constraints on the Permian-Triassic Northern Source Region of the Sverdrup Basin, Canadian Arctic Islands (this issue)

Beranek, L.P., van Staal, C.R., Gordee, S.M., McClelland, W.C., Israel, S., Mihalynuk, M., 2012. Tectonic significance of upper Cambrian-Middle Ordovician mafic volcanic rocks on the Alexander terrane, Saint Elias Mountains, Northwestern Canada. J. Geol. 120, 293-314.

Beranek, L.P., van Staal, C.R., McClelland, W.C., Israel, S, Mihalynuk, M.G., 2013. Baltican crustal provenance for Cambrian-Ordovician sandstones of the Alexander terrane, North American Cordillera: evidence from detrital zircon U-Pb geochronology and Hf isotope geochemistry. J. Geol. Soc. 170, 7-18.

Beranek, L.P., van Staal, C.R., McClelland, W.C., Joyce, N., Israel, S., 2014. Late Paleozoic assembly of the Alexander-Wrangellia-Peninsular composite terrane, Canadian and Alaskan cordillera. Bull. Geol. Soc. Am. 126 (11-12), 1531-1550.

Bingen, B., Nordgulen, O., Viola, G., 2008. A four-phase model for the sveconorwegian orogeny, SW Scandinavia. Nor. J. Geol. 88, 43-72.

Bogdanov, N.A., Khain, V.E., Rozen, O.M., Shipilov, E.V., Vernikovsky, V.A., Drachev, S.S., Kostyuchenko, S.L., Kuzmichev, A.B., Sekretov, S.B., 1998. Tectonic Map of the Kara and Laptev Seas and North Siberia. Russian Academy of Science, Moscow (in Russian).

Bradley, D.C., Dumoulin, J., Layer, P., Sunderlin, D., Roeske, S., McClelland, B., Harris, A.G., Abbott, G., Bundtzen, T., Kusky, T., 2003. Late Paleozoic orogeny in Alaska's Farewell terrane. Tectonophysics 372, 23-40.

Brown, D., Puchkov, V., Alvarez-Marron, J., Bea, F., Perez-Estaun, A., 2006. Tectonic processes in the Southern and Middle Urals: an overview. Geological Society, London, Memoirs 32, pp. 407-419.

Budnikov, V.I., 1976. Patterns of Sedimentation in Carboniferous and Permian of Siberian Platform. Nedra, Moscow 134 p.(in Russian).

Colpron, M., Nelson, J.L., 2011. A Paleozoic NW Passage and the Timanian, Caledonian and Uralian connections of some exotic terranes in the North American Cordillera. In: Spencer, A.M., Embry, A.F., Gautier, D.L., Stoupakova, A.V., Sorensen, K. (Eds.), Arctic Petroleum Geology. Geological Society Memoir 35, pp. 463-484.

Degtyarev, K.E., 2012. Tectonic Evolution of the Early Paleozoic Island Arcs and Continental Crust Formation in Caledonides of Kazakhstan. GEOS, Moscow 289 p. (in Russian).

Dumoulin, J.A., Harris, A.G., Gagiev, M., Bradley, D.C., Repetski, J.E., 2002. Lithostratigraphic, conodont, and other faunal links between lower Paleozoic strata in northern and central Alaska and northeastern Russia. Special Paper of the Geological Society of America 360, pp. 291-312.

Embry, A., 1998. Counterclockwise rotation of the Arctic Alaska Plate: best available model or untenable hypothesis for the opening of the Amerasia Basin. Polarforschung $68,247-255$

Ershova, V.B., Khudoley, A.K., Prokopiev, A.V., 2013. Reconstruction of provenances and tectonic events in the Carboniferous in the northeastern framing of the Siberian platform from U-Pb dating of detrital zircon. Geotectonics 47 (2), 93-100.

Ershova, V.B., Prokopiev, A.V., Khudoley, A.K., Sobolev, N.N., Petrov, E.O., 2015a. Detrital zircon ages and provenance of the Upper Paleozoic successions of Kotel'ny Island (New Siberian Islands Archipelago). Lithosphere 7, 40-45.

Ershova, V.B., Prokopiev, A.V., Khudoley, A.K., Sobolev, N.N., Petrov, E.O., 2015b. U/Pb dating of detrital zircons from Upper Paleozoic deposits of Bel'kovsky Island (New Siberian Islands): critical testing of Arctic tectonic models. Int. Geol. Rev. 57 (2), 199-210.

Ershova, V.B., Prokopiev, A.V., Nikishin, V.A., Khudoley, A.K., Malyshev, N.A., Nikishin, A.M., 2015c. New data on Upper Carboniferous - Lower Permian deposits of Bol'shevik Isl. (Severnaya Zemlya Archipelago). Polar Res. 34, 24558. http://dx.doi.org/10.3402/ polar.v34.24558.

Ershova, V.B., Prokopiev, A.V., Khudoley, A.K., 2015d. Integrated provenance analysis of Carboniferous deposits from Northeastern Siberia: implication for the Late Paleozoic history of the Arctic. J. Asian Earth Sci. 109, 38-49.

Ershova, V.B., Lorenz, H., Prokopiev, A.V., Sobolev, N.N., Khudoley, A.K., Petrov, E.O., Estrada, S., Sergeev, S., Larionov, A., Thomsen, T.B., 2016. The De Long Islands: A missing link in unraveling the Paleozoic paleogeography of the Arctic. Gondwana Res. http://dx.doi.org/10.1016/j.gr.2015.05.016 (in press).

Gehrels, G., 2012. Detrital zircon U-Pb geochronology: current methods and new opportunities. In: Busby, C., Azor, A. (Eds.), Tectonics of Sedimentary Basins: Recent Advances, Chapter 2. Blackwell Publishing Ltd., pp. 47-62.

Gladkochub, D.P. Donskaya, T.V., Wingate, M.T.D., Mazukabzov, A.M., Pisarevsky, S.A. Sklyarov, E.V., Stanevich, A.M., 2010. A one-billion-year gap in the Precambrian history of the southern Siberian craton and the problem of the Transproterozoic supercontinent. Am. J. Sci. 310 (9), 812-825.

Glorie, S., Buslov, M., Zhimulev, F., Safonova, I., 2014. Provenance of early Paleozoic sediments at the southwestern margin if the Siberian Craton: insights from detrital zircon U-Pb geochronology. J. Asian Earth Sci. 82, 115-123.

Gottlieb, E.S., Meisling K.E., Miller, E.L, Mull, C.G, 2014. Closing the Canada Basin: Detrital zircon geochronology relationships between the North Slope of Arctic Alaska and the Franklinian mobile belt of Arctic Canada. Geosphere 10 (6), 1366-1384.

Gramberg, I.S., Ushakov, V.I. (Eds.), 2000. Severnaya Zemlya - Geology and Mineral Resources. VNIIOkeangeologia, St. Petersburg (in Russian)

Gusev, N.I., Rudenko, V.E., Berezhnaya, N.G., Skublov, S.G., Larionov, A.N., 2013. Isotopicgeochemical characteristics and the age (SHRIMP-II) of metamorphic and magmatic rocks in the Kotuikan-Monkhola zone of the Anabar shield. Regional Geol. Metallogeny 54, 45-59 (in Russian). 
Ivanov, K.S., Erokhin, Yu.V., Fedorov, Yu.N., Khiller, V.V., Ponomarev, V.S., 2010. Isotopic and chemical $\mathrm{U}-\mathrm{Pb}$ dating of granitoids from the Western Siberian megabasin. Dokl. Earth Sci. 433 (2), 1070-1073.

Ivanov, K.S., Erokhin, Yu.V., Pisetsky, V.B., Ponomareov, V.S., Pogromskaya, O.E., 2012. New data on the structure of the West-Siberian platform basement. Litosfera 4, 91-106 (in Russian).

Ivanov, K.S., Erokhin, Yu.V., Koroteev, V.A., 2013. First data on early Paleozoic granitoids in the basement of West Siberia. Dokl. Earth Sci. 453 (2), 1193-1196.

Khudoley, A.K., Guriev, G.A., 1994. The formation and development of late Paleozoic basin on the passive margin of the Siberian paleocontinent. In: Beauchamp, B., Embry, A.F., Glass, D. (Eds.), Pangea: Global Environments and Resources. Canadian Society of Petroleum Geologists Memoir 17, pp. 131-143 (Calgary).

Khudoley, A.K., Prokopiev, A.V., 2007. Defining the eastern boundary of the North Asian craton from structural and subsidence history studies of the Verkhoyansk fold and thrust belt. In: Sears, J., Harms, T., Evenchick, C. (Eds.), Whence the Mountains? Enquiries into the Evolution of Orogenic Belts: A Volume in Honor of Raymond A. Price. The Geological Society of America Special Paper Vol. 433, pp. 391-410.

Khudoley, A., Chamberlain, K., Ershova, V., Sears, J., Prokopiev, A., MacLean, J., Kazakova, G., Malyshev, S., Molchanov, A., Kullerud, K., Toro, J., Miller, E., Veselovskiy, R., Li, A., Chipley, D., 2015. Proterozoic supercontinental restorations: constraints from provenance studies of Mesoproterozoic to Cambrian clastic rocks, eastern Siberian Craton. Precambrian Res. 259, 78-94.

Kontorovich, V.A., Kontorovich, A.E., Gubin, I.A., Zoteev, A.M., Lapkovsky, V.V., Malyshev, N.A., Soloviev, M.V., Fradkin, G.S., 2013. The Neoproterozoic-Phanerozoic section of the Anabar-Lena province: structural framework, geological model, and petroleum potential. Russ. Geol. Geophys. 54, 1253-1274.

Korago, E.A., Kovaleva, G.N., Ilyin,V.F., Pavlov, L.G., 1992. Tectonics and Metallogeny of Early Kimmeridgian Orogenic Complexes of Novaya Zemlya. Nedra, St. Petersburg. (in Russian)

Kushnir, D.G., 2006. Paleozoic swells in the north of central and western Siberia. Geotectonics 40 (5), 399-404.

Kuzmichev, A.B., 2009. Where does the South Anyui suture go in the New Siberian islands and Laptev Sea?: implications for the Amerasia basin origin. Tectonophysics 463 (1), 86-108.

Lane, L.S., 2007. Devonian-Carboniferous paleogeography and orogenesis, northern Yukon and adjacent Arctic Alaska. Can. J. Earth Sci. 44 (5), 679-694.

Lawver, L.A., Grantz, A., Gahagan, L.M., 2002. Plate kinematic evolution of the present Arctic region since the Ordovician. In: E.L., Miller, A., Grantz, S.L., Klemperer (Eds.), Tectonic evolution of the Bering Shelf-Chukchi Sea-Arctic Margin and adjacent landmasses, Special Paper. Geological Society of America, Boulder, CO, pp. 333-358.

Lorenz, H., Gee, D.G., Whitehous, M., 2007. New geochronological data on Palaeozoic igneous activity and deformation in the Severnaya Zemlya Archipelago, Russia, and implications for the development of the Eurasian Arctic margin. Geol. Mag. 144, 105-125.

Lorenz, H., Gee, D.G., Simonetti, A., 2008a. Detrital zircon ages and provenance of the Late Neoproterozoic and Palaeozoic successions on Severnaya Zemlya, Kara Shelf: a tie to Baltica. Nor. J. Geol. 88 (4), 235-258.

Lorenz, H., Mannik, P., Gee, D., Proskurnin, V., 2008b. Geology of the Severnaya Zemlya archipelago and the North Kara terrane in the Russian high Arctic. Int. J. Earth Sci. 97, 519-547.

Lorenz, H., Gee, D.G., Korago, E., Kovaleva, G., McClelland, W.C., Gilotti, J.A., Frei, D., 2013. Detrital zircon geochronology of Palaeozoic Novaya Zemlya - a key to understanding the basement of the Barents Shelf. Terra Nova 25 (6), 496-503.

Makariev, A.A. (Ed.), 2013. State Geological Map of the Russian Federation. Scale 1:1 000 000 (Third Generation). Sheet T-45 - 48th. Chelyuskin. Explanatory Note. VSEGEI Press:St. Petersburg. (in Russian)

Malich, N.S. (Ed.), 1999. Geological Map of Siberian Platform and Adjoining Areas. Scale 1: 1500000 (9 Sheets). VSEGEI Press:St. Petersburg. (in Russian)

Malkowski, M.A., Hampton, B.A., 2014. Sedimentology, U-Pb detrital geochronology, and Hf isotopic analyses from Mississippian-Permian stratigraphy of the Mystic subterrane, Farewell terrane, Alaska. Lithosphere 6 (5), 383-398.

McLelland, J.M., Selleck, B.W., Bickford, M.E., 2010. Review of the Proterozoic evolution of the Grenville Province, its Adirondack outlier, and the Mesoproterozoic inliers of the Appalachians. The Geological Society of America Memoir 206, pp. 21-49.

Metelkin, D.V., Kazansky, Yu.A., Vernikovsky, V.A., Gee, D.G., Torsvik, T., 2000. First palaeomagnetic data on the early Palaeozoic rocks from Severnaya Zemlya (Siberian Arctic) and their geodynamic interpretation. Geol. Geofiz. 41, 1816-1820 (in Russian).

Metelkin, D.V., Vernikovsky, V.A., Kazansky, A.Yu., Bogolepova, O.K., Gubanov, A.P., 2005. Paleozoic history of the Kara microcontinent and its relation to Siberia and Baltica: paleomagnetism, paleogeography and tectonics. Tectonophysics 398, 225-243.

Metelkin, D.V., Vernikovsky, V.A., Matushkin, N.Yu., Tolmacheva, T.Yu., Zhdanova, A.I., 2014. First paleomagnetic data for the Early Paleozoic deposits of New Siberian Islands: concerning the formation of the South Anyui Suture and tectonic reconstruction of Arctida. Litosfera 3, 11-31 (in Russian).

Mezhvilk, A.A., Markov, F.G., 1983. State Geological Map of the Russian Federation. Scale 1:1000 000. Sheet R-50-52. Explanatory Note. VSEGEI Publishing House: Leningrad. (in Russian)

Miller, E.L., Toro, J., Gehrels, G., Amato, J.M., Prokopiev, A.V., Tuchkova, M.I., Akinin, V.V., Dumitru, T.A., Moore, T.E., Cecile, M.P., 2006. New insights into Arctic paleogeography and tectonics from U-Pb detrital zircon geochronology. Tectonics 25 (3) (art. no. TC3013).

Miller, E.L., Gehrels, G.E., Pease, V., Sokolov, S., 2010. Stratigraphy and U-Pb detrital zircon geochronology of Wrangel Island, Russia: Implications for Arctic paleogeography. American Association of Petroleum Geologists Bulletin. 94, pp. 665-692.

Miller, E.L., Soloviev, A.V., Prokopiev, A.V., Toro, J., Harris, D., Kuzmichev, A.B., Gehrels, G.E., 2013. Triassic river systems and the paleo-Pacific margin of northwestern Pangea. Gondwana Res. 23 (4), 1631-1645.
Nozhkin, A.D., Turkina, O.M., Bayanova, T.B., Berezhnaya, N.G., Larionov, A.N., Postnikov, A.A., Travin, A.V., Ernst, R.E., 2008. Neoproterozoic rift and within plate magmatism in the Yenisei Ridge: implications for the breakup of rodinia. Russ. Geol. Geophys. 49, 503-519.

Nozhkin, A.D., Kachevskii, L.K., Dmitrieva, N.V., 2013. The Late Neoproterozoic rift-related metarhyolite-basalt association of the Glushikha trough (Yenisei Ridge): petrogeochemical composition, age, and formation conditions. Russ. Geol. Geophys. 54, 44-54.

Parfenov, L.M., Berzin, N.A., Khanchuk, A.I., Badarch, G, Belichenko, V.G., Bulgatov, A.N Dril', S.I., Kirillova, G.L., Kuz'min, M.I., Nokleberg, W., Prokopiev, A.V., Timofeev, V.F., Tomurtogoo, O. and Yan, H., 2003. Model for the formation of orogenic belts of central and Northeast Asia. Tikhookeanskaya Geologiya 6, 7-42. (in Russian)

Parfenov, L.M., Badarch, G., Berzin, N.A., Khanchuk, A.I., Kuzmin, M.I., Nokleberg, W.J. Prokopiev, A.V., Ogasawara, M., Yan, H., 2009. Summary of Northeast Asia geodynamics and tectonics. Stephan Mueller Spec. Publ. Ser. 4, 11-33.

Pease, V., Vernikovsky, V., 1998. The tectonomagmatic evolution of the Taimyr Peninsula: further constraints from new ion-microprobe data. Polarforschung 68, 171-178.

Pease, V., Gee, D.G., Vernikovsky, V., Vernikovskaya, A., Kireev, S., 2001. Geochronological evidence for late-Grenvillian magmatic and metamorphic events in Central Taimyr, northern Siberia. Terra Nova 13, 270-280.

Pease, V., Kuzmichev, A.B., Danukalova, M.K., 2015. The New Siberian Islands and evidence for the continuation of the Uralides, Arctic Russia. J. Geol. Soc. Lond. 172, 1-4

Pogrebitskiy, Yu.E, Lopatin, B.G., 1999. State Geological Map of the Russian Federation. Scale 1:1000 000. S-44-46. Explanatory Note. VSEGEI Publishing House:St. Petersburg (in Russian).

Pogrebitskiy, Yu.E., Shanurenko, N.K., 1998. State Geological Map of the Russian Federation. Scale 1:1000 000. Sheet S-47-49. Explanatory Note. VSEGEI Publishing House: St. Petersburg. (in Russian)

Prokopiev, A.V., Parfenov, L.M., Tomshin, M.D., Kolodeznikov, I.I., 2001. Sedimentary cover of the Siberian platform and adjacent fold-and-thrust belts. In: Parfenov, L.M., Kuzmin, M.I. (Eds.), Tectonics, Geodynamics and Metallogeny of the Territory of the Sakha Republic (Yakutia), pp. 113-155 (in Russian).

Prokopiev, A.V., Toro, J., Miller, E.L., Gehrels, G.E., 2008. The paleo-Lena River - 200 m.y. of transcontinental zircon transport in Siberia. Geology 36 (9), 699-702.

Prokopiev, A.V., Ershova, V.B., Miller, E.L., Khudoley, A.K., 2013. Early Carboniferous paleogeography of the northern Verkhoyansk passive margin as derived from $\mathrm{U}-\mathrm{Pb}$ dating of detrital zircons: role of erosion products of the Central Asian and TaimyrSevernaya Zemlya fold belts. Russ. Geol. Geophys. 54 (10), 1195-1204.

Proskurnin, V.A., Vernikovsky, D.V., Metelkin, B.S., Petrushkov, A.E., Vernikovskaya, A.V., Gavrish, A.A., Bagaeva, N.Yu. Matushkin, N.P. Vinogradova, A.N. Larionov, 2014 Rhyolite-granite association in the Central Taimyr zone: evidence of accretionarycollisional events in the Neoproterozoic. Russ. Geol. Geophys. 55 (1), 18-32.

Puchkov, V.N., 1997. Structure and Geodynamics of the Uralian Orogen. In: Burg, J.-P., Ford, M. (Eds.), Orogeny through Time. Geological Society, London, Special Publications 121, pp. 201-236.

Puchkov, V.N., 2009. The evolution of the Uralian orogeny. Geological Society Special Publication 327, pp. 161-195.

Rivers, T., 2008. Assembly and preservation of lower, mid, and upper orogenic crust in the Grenville Province-implications for the evolution of large hot long-duration orogens. Precambrian Reserach 167, 237-259.

Rozen, O.M., 2003. Siberian craton: tectonic zonation, stages of evolution. Geotectonics 37 (3), 175-192.

Shishlov, S.B., 2003. Cyclostratigraphy of Upper Paleozoic terrigenous deposits in the Taimyr Peninsula. Stratigr. Geol. Correl. 11 (2), 138-151.

Smelov, A.P., Timofeev, V.F., 2007. The age of the North Asian Cratonic basement: an overview. Gondwana Res. 12, 279-288.

Solomina, R.V., 1997. Permian biostratigraphic scheme of Verkhoyanye. Otechestvenaya Geologia 3, 37-43 (in Russian).

Strauss, J.V., Macdonald, F.A., Taylor, J.F., Repetski, J.E., McClelland,W.C., 2013. Laurentian origin for the north slope of Alaska: implications for the tectonic evolution of the Arctic. Lithosphere 5 (5), 477-482.

Till, A.B., Amato, J.M., Aleinikoff, J.N., Bleick, H.A., 2014. U-Pb detrital zircon geochronology as evidence for the origin of the Nome Complex, northern Alaska, and Iimplications for regional and trans-Arctic correlations. In: Dumoulin, J.A., Till, A.B. (Eds.), Reconstruction of a Late Proterozoic to Devonian Continental Margin Sequence, Northern Alaska, Its Paleogeographic Significance, and Contained Base-Metal Sulfide Deposits. Geological Society Of America Special Paper 506, pp. 111-131.

Tochilin, C.J., Gehrels, G.E., Nelson, J., Mahoney, J.B., 2014. U-Pb and Hf isotope analysis of detrital zircons from the Banks Island assemblage (coastal British Columbia) and southern Alexander terrane (southeast Alaska). Lithosphere 6 (3), 200-215.

Turkina, O.M., Nozhkin, A.D., Bayanova, T.B., Dmitrieva, N.V., Travin, A.V., 2007. Precambrian terranes in the southwestern framing of the Siberian craton: isotopic provinces, stages of crustal evolution and accretion-collision events. Russ. Geol. Geophys. 48 (1), $61-70$.

Vernikovskaya, A.E., Vernikovsky, V.A., Sal'nikova, E.B., Yasenev, A.M., Kotov, A.B., Kovach, A.P., Travin, A.V., Yakovleva, S.Z., Fedoseenko, A.M., 2006. Neoproterozoic A-type granites of the Garevka massif, Yenisey Ridge: age, sources, and geodynamic setting. Petrology 14 (1), 50-61.

Vernikovsky, V.A., 1996. Geodynamic Evolution of the Taimyr Folded Region. Publishing House of the Siberian Division of RAS, Novosibirsk (in Russian).

Vernikovsky, V.A., Vernikovskaya, A.E., Pease, V.L., Gee, D.G., 2004. Neoproterozoic orogeny along the Margins of Siberia. In: Gee, D.G., Pease, V.L. (Eds.), The Neoproterozoic Timanide Orogen of eastern Baltica. Geological Society, London, pp. 233-247.

Vernikovsky, V.A., Metelkin, D.V., Vernikovskaya, A.E., Sal'nikova, E.B., Kovach, V.P., Kotov, A.B., 2011. The oldest island arc complex of Taimyr: concerning the issue of the Central-Taimyr accretionary belt formation and paleogeodynamic reconstructions in the Arctic. Dokl. Earth Sci. 436 (2), 186-192. 
Votyakov, S.L., Ivanov, K.S., Erokhin, Yu.V., Khiller, V.V., Bochkarev, V.S., Zakharov, A.V. Korotkov, S.A., 2013. The composition of granites from Yamal basement and their chemical electron microprobe Th-U-Pb dating. Litosfera 3, 57-66 (in Russian).

Yolkin, E.A., Krasnov, V.I., Bakharev, N.K., Belova, E.V., Dubatov, V.N., Izokh, N.G., Klets, A.G., Kontorovich, A.E., Peregoedov, L.G., Sennikov, N.V., Timokhina, I.G., Kromykh, V.G., 2001. Stratigraphy of Oil and Gas Basins of Siberia. Western Siberia. Publishing house of SB RAS, Novosibirsk (in Russian).
Zakharov, Yu.I., Chukhonin, V.F., Proskurnin, V.F., 1993. New isotope-geochemical data for granitoids of the Shrenk-Mamont protrusion of Taimyr peninsula. Doklady AN SSSR 332 (1), 58-61 (in Russian).

Zhang, X., Omma, J., Pease, V., Scott, R., 2013. Provenance of Late Paleozoic-Mesozoic sandstones, Taimyr Peninsula, the Arctic. Geosciences (Switzerland) 3 (3), 502-527.

Zonenshain, L.P., Kuz'min, M.I., Natapov, L.M., 1990. Geology of the USSR: a plate-tectonic synthesis. Geodynamics Series 21. American Geophysical Union, Washington. 